\title{
Pengaruh kreativitas dan profesionalisme terhadap kinerja guru Sekolah Menengah Pertama Negeri di kecamatan Trimurjo kabupaten Lampung Tengah (The influence creativity and professionalism on teacher performance in Public Junior High Schools in Trimurjo district, Central Lampung regency)
}

Roslinawati Kasmur $^{1 *}$, Riyanto ${ }^{2}$, Agus Sutanto ${ }^{3}$

SMP Negeri 1 Trimurjo, Lampung Tengah ${ }^{{ }^{*}}$

Program Studi Magister Administrasi Pendidikan, Universitas Muhammadiyah Metro, Metro ${ }^{2,3}$

linkasmur@gmail.com

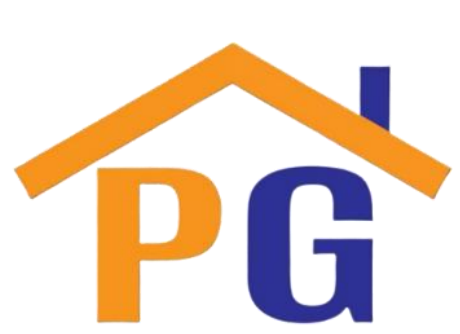

Abstract
Purpose: The purpose of this study was to determine the effect of teacher creativity and professionalism on the performance of teachers in SMP Negeri in Trimurjo district, Central Lampung regency.

Research methodology: The research design is quantitative research or verification research. The method used in this research is an ex post facto approach with a correlational design. The objects of this research are creativity, professionalism and teacher performance. The study population was the teachers at the State Junior High School in Trimurjo District, with a total sample of 63

Riwayat Artikel

Diterima pada 30 Maret 2021

Revisi 1 pada 18 April 2021

Revisi 2 pada 28 April 2021

Revisi 3 pada 4 Mei 2021

Disetujui pada 5 Mei 2021 respondents. The data collection technique used a questionnaire. The analytical tool used is descriptive analysis, simple linear regression analysis and multiple linear analysis with the SPSS program.

Results: The results of hypothesis testing partially have a positive and significant effect on creativity on teacher performance. There is a positive and significant effect of teacher professionalism on performance. Simultaneously the creativity and professionalism of teachers together have a positive and significant effect on teacher performance.

Limitations: This study is still not optimal due to the COVID-19 pandemic, so the authors cannot conduct face-to-face research and observe real school conditions.

Contribution: The results of this study contribute to evaluating and improving the creativity and professionalism of teachers in Trimurjo. Keywords: Creativity, Professionalism, Teacher performance

How to cite: Kasmur, R., Riyanto., \& Sutanto, A. (2021) Pengaruh kreativitas dan profesionalisme terhadap kinerja guru Sekolah Menengah Pertama Negeri di kecamatan Trimurjo kabupaten Lampung Tengah. Jurnal Humaniora dan Ilmu Pendidikan, 1(1), $15-25$.

\section{Pendahuluan}

Kinerja guru merupakan ukuran penting yang dapat menentukan keberhasilan proses pendidikan di masa selanjutnya, maka pendidik diharapkan mampu meningkatkan kinerjanya untuk melaksanakan peran serta tugasnya sebagai guru. Dalam bekerja, pendidik dipengaruhi oleh faktor eksternal serta faktor internal. Faktor internal meliputi: minat, perilaku, intelegensi, kreativitas, profesionalisme pendidik serta motivasi, sementara faktor eksternal meliputi insentif, sarana prasarana, iklim pekerjaan serta lingkup pekerjaan. Untuk mencapai kinerja maksimal agar mendapatkan hasil pembelajaran dan pencapaian tujuan, maka diperlukan kreativitas guru dalam pembelajaran. Kreativitas merupakan daya 
cipta seseorang untuk membuat suatu hal yang baru. Proses pembelajaran memerlukan model pembelajaran, materi, maupun media dari guru untuk peserta didik. Adanya faktor lainnya yang berpengaruh pada sistem kerja pendidik selain kreativitas yakni profesionalisme pendidik. Profesionalisme adalah bentuk penguasaan individu pada tugas dan tanggung jawabnya sebagai pendidik. Guru yang memiliki profesionalitas yang mengerti serta paham terhadap tugas serta kewajibannya. Saat menjalankan tugasnya, pendidik perlu berwawasan serta memiliki informasi yang banyak berhubungan pada materi yang diambilnya.

Berdasarkan pra survey di SMP Negeri kecamatan Trimurjo Lampung Tengah pada 14-19 September 2020 melalui wawancara dengan 15 guru, diperoleh informasi antara lain, dalam pembelajaran, daring terdapat 10 guru yang menggunakan aplikasi classroom, 4 guru yang menggunakan zoom dan classroom, dan sebanyak 1 guru yang melakukan pembelajaran dengan berbagai aplikasi (WA, Zoom, Classroom, Google Form). Tidak semua guru menguasai tata cara menyusun dan menerapkan rencana pelaksanaan pembelajaran daring. Masih ada guru yang belum mengembangkan materi pembelajaran. Materi yang digunakan hanya sebatas mengunduh dari internet dan tidak dikembangkan kembali, dan soal yang diberikan kepada peserta didik berasal dari internet (bukan buatan guru sendiri).

Tabel 1. Penilaian Kinerja Guru Tahun 2019/2020

\begin{tabular}{|c|c|c|c|c|c|}
\hline Kompetensi & $\begin{array}{l}\text { Skor } \\
\text { Ideal }\end{array}$ & $(\%)$ & $\begin{array}{l}\text { Skor } \\
\text { PKG }\end{array}$ & $(\%)$ & Kategori \\
\hline Penilain Kompetensi 1 : Memahami karakter siswa & 56 & 100 & 38 & 68 & Cukup \\
\hline $\begin{array}{l}\text { Penilaian Kompetensi } 2 \text { : Memahami teori belajar serta prinsip kegiatan } \\
\text { belajar yang positif }\end{array}$ & 56 & 100 & 35 & 63 & Cukup \\
\hline Penilaian Kompetensi 3 : Pengembangan kurikulum & 56 & 100 & 36 & 64 & Cukup \\
\hline Penilaian Kompetensi 4 : proses belajar yang positif & 56 & 100 & 40 & 71 & Cukup \\
\hline Penilaian Kompetensi 5 : Pengembangan potensi siswa & 56 & 100 & 30 & 54 & Sedang \\
\hline Penilaian Kompetensi 6 : Komunikasi dengan siswa & 56 & 100 & 35 & 63 & Sedang \\
\hline Penilaian Kompetensi 7 : Penilaian dan evaluasi & 56 & 100 & 40 & 71 & Cukup \\
\hline $\begin{array}{l}\text { Penilaian Kompetensi } 8 \text { : Berkerjasama pada norma hukum, norma } \\
\text { agama, , social serta budaya nasionalisme }\end{array}$ & 56 & 100 & 38 & 68 & Cukup \\
\hline $\begin{array}{l}\text { Penilaian Kompetensi } 9 \text { : Menampilkan kepribadian yang matang serta } \\
\text { tauladan }\end{array}$ & 56 & 100 & 40 & 71 & Cukup \\
\hline $\begin{array}{l}\text { Penilaian Kompetensi } 10 \text { : Keinginan bekerja, rasa bertanggung jawab } \\
\text { yang besar serta bangga jadi pendidik }\end{array}$ & 56 & 100 & 35 & 63 & Cukup \\
\hline $\begin{array}{l}\text { Penilaian Kompetensi } 11 \text { : Bersikap inklusif, tindakan objektif, serta } \\
\text { tidak diskriminatif }\end{array}$ & 56 & 100 & 30 & 54 & Sedang \\
\hline $\begin{array}{l}\text { Penilaian Kompetensi } 12 \text { : berkomunikasi dengan baik pada pendidik, } \\
\text { staf kependidikan, orang tua siswa serta warga. }\end{array}$ & 56 & 100 & 40 & 71 & Cukup \\
\hline $\begin{array}{l}\text { Penilaian Kompetensi } 13 \text { : Penguasaan mata pelajaran, structure, konsep } \\
\text { serta pola pikir pengetahuan yang mendorong pelajaran yang diambil }\end{array}$ & 56 & 100 & 40 & 71 & Cukup \\
\hline $\begin{array}{l}\text { Penilaian Kompetensi } 14: \text { menumbuhkan keprofesionalitasan tentang } \\
\text { tindak reflective }\end{array}$ & 56 & 100 & 30 & 54 & Sedang \\
\hline
\end{tabular}

Sumber: Hasil Penilaian Kinerja Guru di SMP Negeri Trimurjo

Berdasarkan uraian permasalahan yang ada menunjukkan bahwa kualitas kinerja guru belum dapat dikatakan optimal. Kinerja guru yang optimal dapat dilihat dari semua performa guru dimulai pada kegiatan perencanaan hingga ke evaluasi pembelajaran. Apabila guru dapat merancang pembelajaran: membuat dan mengembangkan materi pembelajaran, menyusun RPP, membuat instrumen dan dapat menggunakan berbagai metode pembelajaran maka kinerja guru dapat maksimal. Untuk mencapai kinerja yang maksimal diperlukan suatu kreativitas guru. Guru yang kreatif akan dapat menciptakan hal-hal baru yang bisa membangkit kan minat belajar siswa untuk pembelajaran. Maka, butuh untuk dilakukan penelitian yang membahas tentang "Pengaruh Kreativitas dan Profesional Guru Terhadap Kinerja Guru Sekolah Menengah Pertama Negeri di kecamatan Trimurjo kabupaten Lampung Tengah". 


\section{Tinjauan pustaka dan pengembangan hipotesis \\ Kinerja guru}

Menurut Darmadi (2017: 34) bahwasanya "pekerjaan pendidik yaitu kemampuan yang diperlihatkan pada pendidik untuk mengemban peran serta tugasnya". pekerjaan pendidik bisa dilihat pada berbagai aspek yaitu untuk kegiatan belajar, serta pengembangan profesi. Berhubungan dalam tugas utama pendidik yakni menjalankan perencanaan, serta analisis kegiatan belajar jadi pekerjaan pendidik di sini lebih difokuskan dalam pengertian pekerjaan pendidik pada kegiatan pembelajaran. Pendapat lainnya dikemukakan hingga spesifik oleh Susanto (2018: 203) yang menyatakan bahwa: "Pekerjaan pendidik yaitu perolehan bekerja individu pendidik dengan teliti dari segi kualitas maupun secara kuantitas untuk menjalankan peran serta bertanggung jawab ditunjukkan pada aktivitas bekerja, pengalaman bekerja, ataupun prestasi bekerja". agar bisa memperoleh cara kerja yang positif, pendidik wajib mempunyai kompetensi profesionalitas guru.

Mulyasa (2013: 88) menegaskan "Kinerja pendidik diartikan sebagai suatu usaha agar mendapatkan informasi tentang pengetahuan, keterampilan, nilai, serta peran pendidik saat menjalankan peran serta fungsinya, yang diarahkan pada penampilan, prestasi kerja serta perbuatannya". Maka penilaian cara kerja pendidik paling perlu dalam dilaksanakan dengan periodik dikarenakan dalam mengetahui tingkatan pencapaiannya serta berhasilnya pendidik saat melakukan perannya. Penskoran cara kerja pendidik lebih berfokus apabila terdapat indikator yang di jadikan ukurannya. Supardi (2016: 73) menegaskan bahwa "cara kerja pendidik yang terbaik wajib terpenuhinya kriteria yakni: (a) Kemampuan menciptakan perancangan serta persiapan proses pembelajaran, (b) kemampuan melaksanakan proses pembelajaran, (c) kemampuan memberi hubungan antara satu dan lainnya, (d) kemampuan melakukan penilaian perolehan pembelajaran, (e) kemampuan melaksanakan pengayaan, (f) kemampuan merancang perbaikan belajar".

\section{Kreativitas guru}

Kreativitas yaitu suatu kegiatan menjadikan suatu yang terbaru ataupun menyempurnakan suatu untuk menjadi hal terbaru dalam segala kegiatan manusia. Menurut Asrori (2013: 41) bahwa "Kreativitas adalah kemampuan dalam membuat suatu hal terbaru. Suatu terbaru di sini tak memiliki arti perlu terbaru, namun bisa untuk campuran pada unsur yang telah muncul sebelumnya". Pendapat tersebut menjelaskan bahwasanya kreativitas yaitu kemampuan individu untuk memperoleh suatu hal terbaru. Selanjutnya, berkenaan pada kreativitas guru, maka pengertian guru sangat diperlukan untuk mendefinisikan kreativitas guru. Pada Undang Undang RI Nomor 14 Tahun 2005 berisikan pendidik serta Dosen Pasal 1 Ayat 1 menjelaskan bahwasanya "pendidik yaitu guru yang memiliki profesionalisme yang positif, membimbing, mengajari, menjurukan, menilai, melatih serta mengevaluasi siswa serta pendidikan anak usia dini pada pendidikan formal, pendidikan dasar, serta pendidikan menengah".

Kreativitas mempunyai ciri yaitu suatu yang susah ditemui yang tak seluruh manusia bisa melaksanakannya. Kreativitas bukannya tentang sesuatu yang mudah saat dilaksanakan. Tetapi kreativitas harus diusahakan serta diciptakan lalu dikembangkan secara terus-menerus. Menurut Guntur (2012: 25) bahwa : "ciri kreativitas bisa dibedakan ke dalam ciri kognitif serta non kognitif". Ciri-ciri kognitif sesuai pada 4 ciri berpikir kreatif, yakni: orisinalitas, fleksibel, elaborasi serta kelancaran. Sementara ciri non kognitif tentang motivasi, berperilaku serta pribadi kreatif. Ciri non kognitif sama pentingnya pada ciri kognitif, dikarenakan tidak ditunjang dengan berkepribadian yang sama kreatif individu tak bisa dikembangkan dengan normal. Orang yang kreatif, jika dibandingkan pada yang lainnya, memperlihatkan ciri khas yang beda pada hal intelektualitas, perilaku serta motivasi. Pendidik kreatif yakni pendidik yang menjalankan kegiatan belajar secara optimal pada keahlian serta keilmuan. Apabila kegiatan belajar dilaksanakan secara lancar, dalam hakikatnya yaitu berkreasi. Pendidik terus berkomunikasi pada siswanya mengenai ide baru serta ide lama pada wujud terbaru. 


\section{Profesionalisme guru}

Pendidik memiliki peran yaitu memberi pengarahan pada peserta didik untuk tercapainya tujuan belajar. Profesi yakni pekerjaan dalam menjalankan serta membutuhkan beberapa persyaratan lainnya. Pada Standar Nasional Pendidikan, pasal 28 ayat 3 tentang kompetensi profesionalitas yaitu kekuasaan serta pemahaman bahan ajar dengan mendalam serta luas untuk memungkin kan siswa mencukupi standar kompetensi yang sudah ditentukan pada Standar Nasional Pendidikan. Menurut Syaiful (2013: 41) "kompetensi profesional berpacu dalam tindakan yang memiliki sifat rasionalisme serta memenuhi spesifikasi tertentu untuk menjalankan tugas-tugas kependidikan". Sedangkan menurut Hamzah (2016: 20) "kompetensi profesional berarti seorang pendidik wajib mempunyai informasi yang tinggi atas jenis pelajaran yang diampu, serta memahami metodologi, pada artian mempunyai konsep teoritis serta memilihkan metode saat proses pembelajaran".

Menurut Priansa (2017: 178) kriteria kompetensi yang erat dalam kompetensi profesionalitas pendidik tentang : "memahami struktur, pola pikir keilmuan serta materi yang memenuhi bidang studi yang diambil, memahami standar kompetensi dan serta landasan pelajaran ataupun jenis pembangunan yang diambil, menumbuhkan materi belajar yang diambil dengan tidak monoton, menumbuhkan profesionalitas dengan terus menerus serta melakukan tindak berefleksi, menggunakan manfaat TIK saat menumbuhkan diri dalam berkomunikasi". Sementara itu menurut Anwar (2018: 36) ditegaskan bahwa kemampuan profesional guru meliputi: "Kemampuan pendidik membuat kurikulum, kemampuan pendidik mengajarkan bahan ajar kepada peserta didik, kemampuan memotivasi peserta didik, kemampuan pendidik dalam mengintegrasi kan beberapa jenis pelajaran ataupun materi jadi suatu konsep satu kesatuan".

Pada hubungan tersebut pendidik butuh memperhatikan siswa dengan individu, dikarenakan antara 1 siswa dan yang lainnya mempunyai karakteristik yang berbeda. pendidik perlu berpacu pada pembelajaran, dalam memberi kemudahan pembelajaran untuk semua siswa, untuk bisa mengembangkan potensinya secara optimal. Dalam hal ini, guru harus kreatif, profesional, dan menumbuhkan, dengan memposisikan dirinya yakni (Mulyasa, 2017):

a. Sebagai orang tua yang penuh rasa sayang terhadap para siswanya.

b. Sebagai teman, tempat mengungkapkan, serta mengutarakan perasaan sebagai siswa.

c. Sebagai fasilitator yang terus sigap dalam memberi kelancaran, serta melayani siswa sama kemampuan, minat serta bakat.

d. Memberi sumbangan pikiran pada orang tua agar bisa mengerti masalah yang dihadapi anak serta memberi solusi serta saran pemecahan.

e. Memberi rasa percaya diri, tanggung jawab serta berani.

f. Menumbuhkan kegiatan bersosialisasi yang baik antara siswa, orang asing, serta ruang lingkup masyarakat.

g. Menumbuhkan kreativitasnya.

h. Membantu saat dibutuhkan.

Dalam memenuhi suatu tuntutan diatas, pendidik wajib bisa memaknainya kegiatan belajar, dan menjadi kan proses belajar bagai ajang menciptakan kompetensi serta pembenahan kualitas diri siswa. pendidik yaitu guru sebagai panutan, tokoh serta identifikasi untuk siswa, seta lingkungan masyarakat. Sebab, output mendidik adalah supaya anak didik menjadi anak yang akhlakul karimah. Maka, pendidik wajib mempunyai standar kualitas pribadi, yang tercakup pada tanggung jawab, berani, berwibawa, disiplin serta mandiri..

\section{Metode penelitian}

Berlandaskan tujuan pada penelitian ini yakni mengujikan pengaruh antar kreativitas pendidik serta kompetensi profesionalisme pendidik pada cara kerja pendidik, maka penelitian ini memakai pendekatan expost factor dengan perancangan korelasional. Sehingga pada penelitian tersebut tak mengadakan perlakuan pada variabel tetapi hanya mengungkap fakta yang sudah ada. Artinya tidak terjadi manipulasi pada variabel tersebut. Penelitian ini menempatkan kreativitas guru, kompetensi 
profesionalitas pendidik sebagai variabel bebas $(X)$ serta cara kerja pendidik menjadi variabel terikat (Y). Penelitian tersebut diselenggarakan di SMP kecamatan Trimurjo kabupaten Lampung Tengah. Pada penelitian ini, yang menjadi populasi pada penelitian tersebut yaitu pendidik yang terdapat dalam SMPN di kecamatan Trimurjo Lampung Tengah. Berdasarkan data yang ada di sekolah, dengan total keseluruhan 164 orang. Menggunakan teknik Sampling yang dipakai yaitu proporsional random sampling. Sampel merupakan bagian ataupun wakil populasi yang diteliti. Dalam mendapatkan sampel yang mewakili populasi dengan keseluruhan jadi sampel di ambil memakai rumus slovin. Apabila jumlah populasi pada penelitian tersebut yaitu 164 dan taraf error (e) sebesar 10\% yaitu 63 responden.

Adanya instrumen pengumpulan data yang dipakai yakni:

a. Data Primer

Instrumen data primer yaitu data yang didapatkan dengan langsung pada pihak yang merupakan sumber utama penelitian, yakni data yang berdasarkan pada jawaban ataupun kuesioner yang disebarkan pada sampel yang dipilih. Data primer pada penelitian tersebut dari jawaban pendidik SMPN di kecamatan Trimurjo yang berkaitan pada pengumpulan data berkenaan kreativitas pendidik, profesionalisme pendidik serta cara kerja guru.

b. Data Sekunder

Data sekunder yaitu sebuah data penguat yang dihasilkan dari lapangan. Data sekunder yang biasa diperoleh dari lapangan tentang data hasil dokumentasi berhubungan pada variabel penelitian, seperti foto, diagram, gambar, serta sebagainya.

\section{Teknik analisis data penelitian}

Analisis deskriptif

Analisis deskriptif dipakai agar mendeskripsikan setiap indikator pada masing-masing variabel. Pada analisis ini akan diperoleh skor dari tiap indikator variabel dalam setiap kuisionernya untuk selanjutnya dihitung jumlah persentase dari setiap kriteria dalam pengukuran setiap variabel penelitian.

\section{Pengujian persyaratan analisis}

Uji normalitas

Uji normalitas dipakai dalam menguji sebuah model regresi, variabel dependen, variabel independen ataupun keduanya memiliki distribusi normal atau tidak. Model regresi yang bagus yaitu distribusi normal ataupun mendekati normal. Salah satu uji kenormalan data yaitu dengan uji KolmogorovSmirnov. Kolmogorov-Smirnov pada menguji kenormalan data dilaksanakan secara prinsip membandingkan probabilitas kumulatif pada data empirik secara distribusi normal. Dengan memakai aplikasi SPSS.

Uji homogenitas

Uji homogenitas dipakai agar memperlihatkan bahwasanya 2 ataupun lebih tim data sampel berasal pada populasi yang mempunyai variasi yang sesuai. Uji homogenitas dipakai agar mengerti apakah berapa varian populasi yaitu sesuai ataupun tak sesuai. Berlandaskan kedua pendapat tersebut maka uji homogenitas dilakukan dalam mengetahui apakah berapa varian populasi data yakni sesuai ataupun tak sesuai. Uji tersebut dilaksanakan untuk prasyarat pada analisis independent sample uji test serta ANOVA.

Uji linieritas

Uji linieritas memiliki tujuan dalam mengetahui apakah 2 variabel memiliki kaitan yang linear ataupun tidak dengan berkesinambungan. Uji ini digunakan untuk prasyarat pada analisis korelasi ataupun regresi linear. Pengujian dalam SPSS saat memakai Test for Linearity dalam taraf signifikansi 0,05. 2 variabel dinyatakan memiliki keterkaitan yang linear bila signifikansi (Linearity) kurang dari 0,05 (Sugiyono, 2016: 194).

\section{Pengujian hipotesis}

a. Analisis Regresi Linier Sederhana

Analisis regresi linier sederhana pada penelitian tersebut dengan rumus persamaan yakni: 
$\mathrm{Y}=\mathrm{a}+\mathrm{bX}$

Selanjutnya dilakukan uji hipotesis agar mengetahui pengaruh variabel bebas pada variabel terikat yakni pengaruh kreativitas pendidik pada cara kerja pendidik serta pengaruh profesionalisme terhadap kinerja guru. Dan untuk mengukur seberapa besar pengaruh pada setiap variabel tersebut bisa dilihat pada nilai koefisien determinasi (R2) yang akan dikalikan 100 agar mengetahui beberapa persen besaran dampak variabel bebas terhadap variabel terikat.

b. Analisis Regresi Linier Berganda

Analisis regresi berganda adalah prosedur dimana dalam melewati formulasi persamaan matematis, hendak di ramalkan nilai variabel random continue berlandaskan nilai variabel kuantitatif lain nya yang diketahui. Di mana variabel bebas atau kreativitas guru serta profesionalisme di dalam mewujudkan variabel terikat atau kinerja guru, maka akan dipakai persamaan regresi ganda, dimana rumus persamaannya yakni:

$\mathrm{Y}=\mathrm{a}+\mathrm{b} 1 \mathrm{X} 1+\mathrm{b} 2 \mathrm{X} 2$

\section{Hasil dan pembahasan}

\section{Kinerja guru}

Penilaian variabel cara kerja pendidik pada penelitian tersebut terdiri dari 9 indikator, dengan perolehan tiap indikator adalah sebagai berikut:

Tabel 2. Persentase per indikator variabel Kinerja Guru

\begin{tabular}{clccc}
\hline No. Indikator & \multicolumn{1}{c}{ Persentase } & Kriteria \\
\hline 1 & $\begin{array}{l}\text { Kemampuan menciptakan perancangan serta persiapan } \\
\text { pembelajaran }\end{array}$ & $60,1 \%$ & Cukup baik \\
2 & $\begin{array}{l}\text { Kemampuan melakukan kegiatan belajar } \\
3\end{array}$ & Kemampuan mengadakan keterkaitan antara individual & $71,7 \%$ & Baik \\
4 & Kemampuan melakukan penilaian perolehan & $74,6 \%$ & Baik \\
5 & Kemampuan untuk melakukan penyaringan & $96,1 \%$ & Sangatt baik \\
6 & Kemampuan untuk melakukan perbaikan nilai & $76,5 \%$ & Baik \\
7 & Kemampuan menguasai materi & $73 \%$ & Baik \\
8 & Kemampuan menguasai metode dan strategi dalam & $91,4 \%$ & Sangat baik \\
& pembelajaran & & Sangat baik \\
9 & Kemampuan mengelola kelas & & $71 \%$ & Baik \\
\hline
\end{tabular}

Sumber: Pengolahan data hasil penelitian, 2021

Berlandaskan tabel diatas bahwasanya mean kinerja guru adalah sebesar 75,7\% sehingga secara keseluruhan termasuk dalam kategori baik, namun masih memerlukan perbaikan sehingga dapat meningkat menjadi kriteria sangat baik seperti peningkatan dalam hal menciptakan dan mengembangkan produk pembelajaran, keberanian dalam menciptakan hal baru dalam pembelajaran serta dalam hal mengatasi masalah dalam pembelajaran. Diharapkan dengan peningkatan beberapa indikator tersebut maka nantinya kinerja guru dapat lebih meningkat lagi.

Tabel 3. Distribusi frekuensi kategori cara kerja pendidik

\begin{tabular}{clcc}
\hline No. & Kategori Kinerja Guru & $\boldsymbol{F}$ & \% \\
\hline 1 & Sangat baik & - & - \\
2 & Baik & 63 & $100 \%$ \\
3 & Cukup & - & - \\
4 & Kurang baik & - & - \\
5 & Tidak baik & - & - \\
\hline
\end{tabular}

Sumber: Pengolahan data hasil penelitian, 2021 
Hasil tersebut menunjukkan bahwa untuk indikator kinerja guru sudah baik namun masih memerlukan peningkatan dimana masih terdapat beberapa indikator yang masih dalam kategori cukup dan kurang baik.

\section{Kreativitas guru}

Penilaian variabel kreativitas guru dalam penelitian ini terdiri dari 10 indikator, dengan perolehan tiap indikator adalah sebagai berikut:

Tabel 4. Persentase per indikator variabel Kreativitas Guru

\begin{tabular}{clcc}
\hline No. & \multicolumn{1}{c}{ Indikator } & Persentase & Kriteria \\
\hline 1 & Menciptakan/mengembangkan produk & $57 \%$ & Cukup baik \\
2 & Orisinalitas & $44,8 \%$ & Baik \\
3 & Menghasilkan penemuan & $65,7 \%$ & Baik \\
4 & Menemukan ide baru & $50,8 \%$ & Kurang \\
5 & Berpikir kreatif & $50,2 \%$ & Kurang \\
6 & Memiliki keberanian & $53,5 \%$ & Kurang \\
7 & Memiliki motivasi tinggi & $54,6 \%$ & Kurang \\
8 & Bersikap dewasa dan peka terhadap masalah & $66,7 \%$ & Cukup \\
9 & Percaya diri dan tidak tergantung orang lain & $73,2 \%$ & Baik \\
10 & Memiliki banyak ide & $69,2 \%$ & Baik \\
\hline & Rata-rata kreativitas guru & $\mathbf{6 0 , 4 \%}$ & Cukup \\
\hline
\end{tabular}

Sumber: Pengolahan data hasil penelitian, 2021

Berlandaskan tabel diperlihatkan bahwa rata-rata kreativitas guru adalah sebesar 60,4\% sehingga secara keseluruhan termasuk dalam kategori cukup, sehingga masih memerlukan perbaikan sehingga dapat meningkat menjadi kriteria baik seperti perbaikan dalam indikator orisinalitas, menemukan ide, berpikir kreatif, keberanian membuat media pembelajaran baru, menciptakan dan mengembangkan produk pembelajaran, dan dewasa menghadapi masalah dan menghasilkan ide. Diharapkan dengan peningkatan beberapa indikator tersebut maka kreativitas guru dapat lebih meningkat.

Adapun untuk mengetahui pembagian kategori kreativitas guru secara terperinci bisa dilihat dalam tabel dibawah:

Tabel 5. Distribusi frekuensi kategori kreativitas pendidik

\begin{tabular}{clcc}
\hline No. & Kategori Kreativitas Guru & $\boldsymbol{F}$ & \% \\
\hline 1 & Sangat baik & - & - \\
2 & Baik & 1 & $1,6 \%$ \\
3 & Cukup & 61 & $96,8 \%$ \\
4 & Kurang baik & 1 & $1,6 \%$ \\
5 & Tidak baik & - & - \\
\hline
\end{tabular}

Sumber: Pengolahan data perolehan penelitian, 2021

Berlandaskan tabel tersebut bisa diketahui bahwasanya kreativitas guru sebagian besar masih termasuk dalam kriteria cukup $(96,8 \%)$ dan terdapat masing-masing 1,6\% guru dengan kreativitas dalam kategori baik dan kurang baik. Hasil tersebut menunjukkan bahwa untuk indikator kreativitas guru sudah baik namun masih memerlukan peningkatan dimana masih terdapat beberapa indikator yang masih dalam kategori cukup dan kurang baik.

\section{Profesionalisme guru}

Penilaian variabel profesionalisme guru dalam penelitian ini terdiri dari 7 indikator, dengan perolehan tiap indikator adalah sebagai berikut:

Tabel 6. Persentase per indikator variabel profesionalisme guru

\begin{tabular}{clcc}
\hline No & \multicolumn{1}{c}{ Indikator } & Persentase & Kriteria \\
\hline 1 & Memenuhi syarat atau kualifikasi pendidik & $84,1 \%$ & Sangat baik \\
2 & Menguasai SK/KD & $74 \%$ & Baik
\end{tabular}


4 Menguasai dan mengembangkan kurikulum

5 Mengintegrasikan berbagai bidang studi menjadi satu kesatuan

Sumber: Pengolahan data perolehan penelitian, 2021

Berlandaskan tabel bisa di lihat bahwasanya rata-rata profesionalisme guru adalah sebesar 69,5\% sehingga secara rata-rata termasuk dalam kategori baik, namun masih memerlukan perbaikan sehingga dapat meningkat menjadi kriteria sangat baik seperti peningkatan dalam indicator meningkatkan profesionalisme, menguasai dan mengembangkan kurikulum, mengintegrasikan beberapa jenis pelajaran jadi satu kesatuan serta memanfaatkan teknologi informasi terkini. Diharapkan dengan peningkatan indikator tersebut maka profesionalisme guru dapat lebih meningkat lagi.

Adapun untuk mengetahui pembagian kategori profesionalisme guru secara terperinci bisa dilihat dalam tabel dibawah:

Tabel 7. Distribusi frekuensi kategori profesionalisme pendidik

\begin{tabular}{clcc}
\hline No. & Profesionalisme Guru & $\boldsymbol{F}$ & \% \\
\hline 1 & Sangat baik & - & - \\
2 & Baik & 10 & $15,9 \%$ \\
3 & Cukup & 53 & $84,1 \%$ \\
4 & Kurang baik & - & - \\
5 & Tidak baik & - & - \\
\hline
\end{tabular}

Sumber: Pengolahan data perolehan penelitian, 2021

Berlandaskan tabel di atas bisa di ketahui bahwasanya profesionalisme guru sebagian besar termasuk dalam kriteria cukup $(84,1 \%)$. Hasil tersebut menunjukkan bahwa indikator profesionalisme guru masih perlu ditingkatkan.

Dalam mengujikan hipotesis tersebut dilakukan uji regresi linier ganda menggunakan SPSS Ver. 24 pada perolehan yaitu:

Tabel 8. Uji Regresi Linier Sederhana $\mathrm{X}_{1}$ serta $\mathrm{X}_{2}$ pada $\mathrm{Y}$

\begin{tabular}{|c|c|c|c|c|c|c|}
\hline \multirow{2}{*}{\multicolumn{2}{|c|}{ Model }} & \multicolumn{3}{|c|}{ Coefficients $^{\mathrm{a}}$} & \multirow{3}{*}{$\mathrm{t}$} & \multirow{3}{*}{ Sigg. } \\
\hline & & \multicolumn{2}{|c|}{ Unstandardised Coefficients } & \multirow{2}{*}{$\begin{array}{c}\text { Standardised } \\
\text { Coefficients } \\
\text { Behta }\end{array}$} & & \\
\hline & & B & Stdz. Eror & & & \\
\hline \multirow[t]{3}{*}{$\overline{1}$} & (Constan) & 54,387 & 5,422 & & 10,032 & 000 \\
\hline & Kreativitas & ,157 & ,065 & ,287 & 2,426 & ,018 \\
\hline & Profesionalisme & 170 & 068 & 295 & 2,490 & 016 \\
\hline
\end{tabular}

a. Dependen Variabel: Kinerja

Sumber: Perolehan pengolahan data SPSS ver.24, 2021

Berlandaskan tabel perolehan perhitungan diperoleh nilai konstanta 54,387 dan nilai koefisien regresi 0,157 dan 0,170 hingga bisa ditulis persamaan regresi nya yaitu:

$\mathrm{Y}^{\wedge}=54,387+0,157 \mathrm{X}_{1}+0,170 \mathrm{X}_{2}$.

Nilai konstanta (a) yang bernilai 54,387yang menunjukkan bahwa kinerja guru akan sebesar 54,387jika tidak dipengaruhi oleh variabel kreativitas dan profesionalisme guru. Koefisien regresi kreativitas guru $\left(\mathrm{X}_{1}\right)$ adalah 0,157 yang menunjukkan jika kreativitas guru $\left(\mathrm{X}_{1}\right)$ terdapat kenaikan $1 \%$, jadi cara kerja pendidik akan mengalami peningkatan sebanyak $15,7 \%$ dengan asumsi variabel lain tetap. Koefisien regresi profesionalisme guru $\left(\mathrm{X}_{2}\right)$ adalah 0,170 yang menunjukkan jika profesionalisme guru $\left(\mathrm{X}_{2}\right)$ terdapat peningkatan $1 \%$, jadi cara kerja pendidik akan mengalami peningkatan sebanyak $17 \%$ pada asumsi variabel lainnya tetap. 
Tabel 9. Tabel Anova $X_{1}$ serta $X_{2}$ pada $Y$

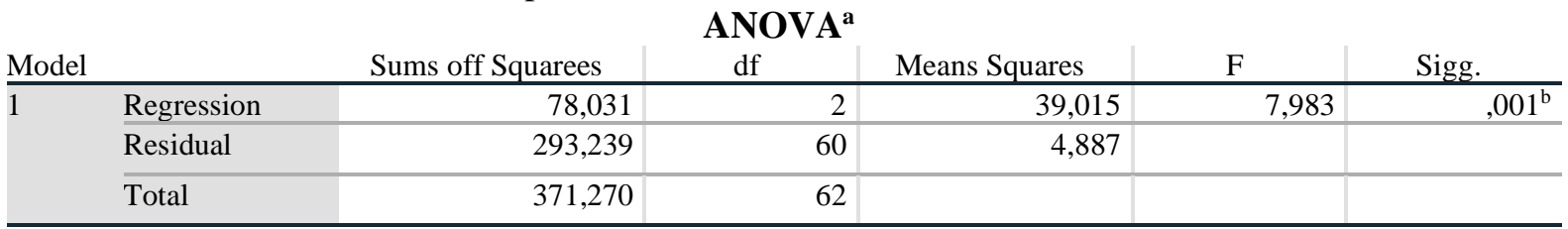

a. Dependen Variabel: Kinerja

b. Predictor: (Constan), Profesional, Kreatifitas

Sumber: Hasil pengolahan data SPSS ver. 24, 2021

Nilai $F_{\text {hitung }} 7,983>F_{\text {tabel }}: 3,150$ serta Nilai Signifikan sebesar 0,001lebih kecil dibandingkan pada nilai $\alpha: 0,05$ yang artinya bahwasanya kreativitas serta profesional pendidik dengan simultan mempunyai pengaruh yang signifikan pada kinerja pendidik, atau dapat disebut makin besar rasa kreativitas serta profesional pendidik maka makin besar juga kinerja pendidik. Berdasarkan hasil ini bisa disimpulkan bahwasanya hipotesis Ha yang diterima ataupun adanya pengaruh kreativitas serta profesional pendidik pada kinerja pendidik SMPN di kecamatan Trimurjo kabupaten Lampung Tengah.

Table 10. Model Summary $\mathrm{X}_{1}$ dan $\mathrm{X}_{2}$ terhadap $\mathrm{Y}$

\section{Model Sumary}

\begin{tabular}{ll|r|r|r} 
Modhel & \multicolumn{2}{|l|}{ R Squares } & Adjuste R Squares & Stds. Eror off the Estimated \\
\hline 1 &, $458^{\mathrm{a}}$ &, 210 &, 184 & 2,211 \\
\hline
\end{tabular}

a. Predictor: (Constan), Profesional

Sumber: Hasil pengolahan data SPSS ver. 24, 2021

Berdasarkan nilai koefisien determinasi R2 diperoleh sebanyak 0,210 yang artinya bahwa kreativitas dan profesionalisme guru memberi dampak sebanyak $21 \%$ pada cara kerja pendidik sedangkan sisa nya yaitu $79 \%$ dipengaruhi oleh variabel lainnya di luar variabel yang akan diteliti.

Berdasarkan hasil penelitian maka dapat dibahas pengaruh dari tiap variabel penelitian sebagai berikut: a. Pengaruh Kreativitas pada cara kerja pendidik

Berdasarkan analisis perolehan penelitian dapat diketahui bahwasanya ada dampak yang baik serta berkesinambungan kreativitas guru pada cara kerja pendidik. Hasil ini menjelaskan bahwa kreativitas pendidik mempunyai dampak baik pada cara kerja pendidik atau dapat diartikan apabila pendidik memiliki kreativitas yang positif maka akan menambah cara kerja pendidik dengan baik. Jika dilihat dari indikator dari kreativitas guru, maka indikator yang menonjol atau dengan skor tertinggi dalam kreativitas guru adalah indikator dalam hal kepercayaan diri dan tidak tergantung orang lain sedangkan indikator dengan rata-rata kategori yang rendah diantaranya yaitu indikator orisinalitas, berpikir kreatif, menemukan ide baru, memiliki keberanian dan motivasi yang kurang. Dari analisa tersebut maka kelemahan dari kreativitas guru yang dominan adalah orisinalitas dan kemampuan menciptakan produk pembelajaran baru karena kurangnya ide yang dapat dimunculkan selama proses pembelajaran.

b. Pengaruh Profesionalisme terhadap cara kerja pendidik

Berlandaskan perolehan analisa data didapatkan hasil bahwasanya ada dampak yang baik serta berkaitan pada profesionalitas pendidik pada cara kerja pendidik. Nilai t hitung yang positif memperlihatkan bahwasanya guru profesional mempunyai kaitan searah dan memberikan dampak baik pada cara kerja pendidik, diartikan apabila pendidik itu profesional sebab guru tersebut memiliki kinerja yang tinggi. Jika dilihat dari indikator dari profesionalisme guru, maka indikator yang menonjol atau dengan skor tertinggi dalam profesionalisme guru adalah syarat dan kualifikasi pendidik dan penguasaan materi, sedangkan indikator dengan skor terendah adalah mengikuti kegiatan peningkatan profesionalitas, penguasaan dan pengembangan kurikulum serta kemampuan menggunakan teknologi informasi. Kondisi tersebut mengingat sebagian besar guru merupakan guru yang sudah lama sehingga cenderung susah mengikuti perkembangan teknologi yang sangat cepat saat ini dan ditambah lagi 
dengan jarangnya mengikuti kegiatan seminar atau pelatihan baik karena keengganan dari guru itu sendiri ataupun memang karena jarangnya dilakukan kegiatan seminar ataupun pelatihan bagi guruguru tersebut.

c. Pengaruh kreativitas serta Profesionalitas pada cara kerja pendidik

Berlandaskan hasil dianalisis variabel kreativitas guru dan profesionalisme guru dengan bersamaan atau simultan berdampak pada cara kerja pendidik, disebut kreativitas pendidik serta profesionalisme pendidik jika diterapkan secara simultan akan lebih meningkatkan cara kerja pendidik di SMPN sekecamatan Trimurjo. Jika dilihat pada indikator dari cara kerja pendidik, maka indikator yang menonjol atau dengan skor tertinggi adalah dalam hal melakukan penilaian hasil dan penguasaan materi pembelajaran, sedangkan indikator dengan skor terendah adalah kemampuan menciptakan rancangan serta persiapan pembelajaran. Pencapaian kinerja maksimal harus didukung pada beberapa faktor tentunya berpengaruh pada cara kerja pendidik. Cara kerja pendidik berhubungan pada hasil pelaksanaan pembelajaran maka juga berhubungan dengan bagaimana guru merancang dan melaksanakan pembelajaran itu dengan baik. Perencanaan dan pelaksanaan pembelajaran membutuhkan kreativitas dan profesionalisme guru dalam pembelajaran. Kreativitas guru untuk menciptakan atau mengembangkan suatu pembelajaran yang baik dalam pelaksanaan pembelajaran, dapat mengembangkan metode-metode pembelajaran yang sudah ada sehingga dapat dikemas dan disesuaikan dengan kondisi sekolah maupun kondisi belajar peserta didik pada saat itu. Selanjutnya, kreativitas tersebut harus didukung dengan profesionalisme yang baik pula, dalam meraih cara kerja pendidik secara optimal harus diperlukan profesionalisme guru yang tinggi dalam pembelajaran. Profesionalisme mengacu pada kemampuan pendidik saat memahami peran serta bertanggung jawab saat pembelajaran.

\section{Kesimpulan}

Berlandaskan perolehan analisa data serta pembahasannya, bisa disimpulkan bahwasanya:

Terdapat pengaruh kreativitas pada cara kerja pendidik SMPN di kecamatan Trimurjo kabupaten Lampung Tengah. Terdapat pengaruh profesionalisme pendidik pada cara kerja pendidik SMPN di kecamatan Trimurjo kabupaten Lampung Tengah. Terdapat pengaruh kreativitas serta profesionalitas pendidik secara bersamaan pada cara kerja pendidik SMPN di kecamatan Trimurjo kabupaten Lampung Tengah.

\section{Limitasi dan studi lanjutan}

Limitasi ataupun kelemahan dalam penelitian berada dalam saat melakukan kegiatan penelitian.

Penulis sadar bahwasanya pada satu penelitian mengalami berapa kesulitan. Salah satu faktor yang menjadikan terhambatnya saat penelitian tersebut yaitu waktu serta tempat penelitian. Penelitian masih belum optimal karena pandemi COVID-19 sehingga penulis tidak bisa melakukan penelitian secara tatap muka dan mengamati kondisi sekolah yang sesungguhnya. Dikarenakan keterbatasan waktu serta tempat penelitian, penulis melibatkan pendidik agar memudahkan penelitian dengan menggunakan google formulir. Semoga di masa akan datang dapat melakukan penelitian dengan lebih leluasa.

\section{Ucapan terima kasih}

Terimakasih untuk semua yang selalu memotivasiku, mendukungku, dan selalu memberikan yang terbaik untukku. Terimakasih kalian yang selalu memberikan semangat, membantu dan mendukung dengan penuh ketulusan hati.

\section{Referensi}

Anwar, Muhammad. (2018). Menjadi Guru Profesional. Jakarta: Prenada Grup.

Asrori, Muhammad. (2013). Psikologi Perkembangan. Bandung: CV Wacana Prima.

Darmadi. (2017). Pengembangan Model dan Metode Pembelajaran dalam Dinamika Belajar Siswa. Yogyakarta: Deepublish.

Guntur, Setiawan. (2012). Implemetasi dalam Birokrasi Pembangunan. Bandung: Remaja Rosdakarya Hamzah, B. (2016). Perencanaan Pembelajaran. Jakarta: Bumi Aksara.

Mulyasa. (2017). Menjadi Guru Profesional. Bandung: PT Remaja Rosdakarya. 
Priansa, Donni Juni.2017. Pengembangan Strategi dan model Pembelajaran. Bandung: CV Wacana Prima.

Sugiyono. (2016). Metode Penelitian Kuantitatif, Kualitatif dan R\&D. Bandung: Alfabeta

Supardi. (2016). Kinerja Guru. Jakarta: PT. Raja Grafindo Persada.

Susanto. (2018). Teori Belajar dan Pembelajaran. Jakarta: Prenada Grup.

Syaiful, Sagala. (2013). Konsep dan Makna Pembelajaran. Bandung: Alfabeta.

Undang-undang No 14 Tahun 2005 Tentang Guru dan Dosen. 